\title{
LUT
}

University

\section{From Equivocality to Reflexivity in Biodiversity Protection}

Quarshie Anne, Salmi Asta, Wu Zhaohui

This is a Post-print version of a publication

published by Sage

in Organization and Environment

DOI: $10.1177 / 1086026619837122$

Copyright of the original publication: () The Author(s)

Please cite the publication as follows:

Quarshie A., Salmi A., Wu Z. (2019). From Equivocality to Reflexivity in Biodiversity Protection. Organization and Environment. DOI: 10.1177/1086026619837122

This is a parallel published version of an original publication. This version can differ from the original published article. 


\title{
From equivocality to reflexivity in biodiversity protection
}

Cite as: Quarshie, A. M., Salmi, A., \& Wu, Z. (2019). From equivocality to reflexivity in biodiversity protection. Organization \& Environment. DOI: 10.1177/1086026619837122

\begin{abstract}
This paper focuses on the silent conversations by individual change makers reflecting upon their concerns in relation to their social and natural worlds. We investigate the internal and external deliberations that informants have by using a qualitative theory building approach in the empirical context of a biodiversity protection issue field in Finland. We conduct 27 interviews with individual change makers representing three types of organizations: government agencies, nonprofit organizations, and businesses. We seek to understand how change makers advancing biodiversity protection reflexively manage the uncertainty and equivocality they face in the interstitial issue field in the course of their change efforts. Our results show that change makers engage in three iterative actions around the issue of biodiversity: filtering, modeling, and translating. They therefore find nuanced ways to convey the biodiversity issue to their stakeholders and, in this way, promote the engagement of other organizational and individual actors in its protection.
\end{abstract}

Keywords: Biodiversity protection, Reflexivity, Institutional theory, Interstitial issue field, Equivocality, Qualitative research 


\section{INTRODUCTION}

“...we don't really know what people actually understand about biodiversity and, in a way, how we could make it easier for them to comprehend. I think these two different worlds [of business and biodiversity], they don 't meet." (Specialist/Counsellor, Government 01)

Biodiversity loss is one of the most serious problems that humanity faces (Ripple et al., 2017). Biodiversity refers to the variability of life on the planet, and it comprises genetic diversity (within species), as well as the diversity between species and broader ecosystems (Convention on Biological Diversity (CBD), 2005; Grigg, 2007). During the past 50 years, humaninduced changes to ecosystems have occurred faster than ever in the history of mankind, and the world appears to have entered a sixth mass extinction event (WWF, 2016; Stockholm Resilience Centre, 2018). This crossing of the planetary boundary for biodiversity loss (Whiteman, Walker, \& Perego, 2013; Steffen et al., 2015) has serious consequences because nature and ecosystems ultimately support all forms of life and civilization on earth (Kolbert, 2014).

Because of the complexity of the issue and the lack of a clear solution to it, biodiversity loss is considered a grand challenge (Churchman, 1967; Ferraro, Etzion, \& Gehman, 2015; George et al., 2016; Grodal \& O’Mahony, 2017). While grand challenges, such as biodiversity loss or climate change, do not necessarily affect ordinary people's lives and daily activities in a direct way, those who are concerned about these problems often struggle because such issues are interconnected and appear way beyond one actor's control (Ripple et al., 2017; IPCC, 2018). This creates additional burdens and cognitive struggles for these individuals (Schabram \& Maitlis, 2017; Sonenshein, DeCelles, \& Dutton, 2014). The issue of biodiversity, in particular, is unique in that the scale of its destruction is difficult even for experts to see and calculate (Steffen et al., 2015; Stockholm Resilience Center, 2018; Hanski, 2016). This is one of 
the main reasons why in the popular press and in public debates, biodiversity loss is overshadowed by other sustainability problems, such as climate change. Moreover, the fact that many individuals have a personal connection to nature implies that working for biodiversity protection easily becomes more than a work role demand: instead, it becomes an existential quest. For individuals who identify and engage strongly with the issue, the emotional disengagement and complacency of others can be puzzling and difficult to accept (Sonenshein et al., 2014). These contradictions can result in an extreme cognitive struggle for individual change makers who are addressing the issue (Archer, 2007).

In this study, we examine the reflexive processes by individual change makers seeking to tackle the planetary boundary grand challenge of biodiversity loss. Our empirical context is Finland, a country that contributes to biodiversity loss via the high ecological footprint of its citizens and is expected to see considerable changes in biodiversity because its loss is amplified by climate change, and temperatures are rising particularly fast in the Arctic area (CAFF, 2015). Moreover, the country is a unique context for studying biodiversity efforts because it is one of the 21 national or regional government actors actively involved in the Global Partnership for Business and Biodiversity (CBD, 2014; 2018). In fact, the Finnish government has launched a major campaign that seeks to engage corporate actors in the work for biodiversity. As a result, several dozen firms have, during the past five years, participated in government-funded biodiversity-related training programs, as well as started to make voluntary commitments and changes to business practices related to biodiversity conservation. These programs and additional activities on biodiversity protection bring together organizations from various sectors with different priorities, motives, and logics, thus forming an interstitial issue field (Ziestma et al., 2017). 
We conduct a qualitative theory-building study in this interstitial issue field focused on creating change and action for biodiversity protection. Issue fields are formed "around issues that bring together various field constituents with disparate purposes" (Hoffman, 1999, p. 352), and interstitial issue fields arise in "interstitial locations, drawing members from multiple fields and logics, with the purpose of negotiating coordination to respond to emerging issues or opportunities" (Ziestma et al., 2017, p. 401). Interstitial fields are likely to emerge when the issue is one that the people are interested in or care about across multiple fields. In the interstitial issue field where we conducted our study, government agencies, nongovernmental organizations (NGOs), forestry companies, and environmental scientists traditionally gathered around the issue of biodiversity protection. However, because of recent government-initiated efforts, the issue field has expanded and begun drawing additional participants from various sectors and business industries. Considerable uncertainty is present in this context, as individuals representing different types of organizations and with competing institutional logics come together around the multifaceted and emotionally demanding issue of biodiversity preservation.

In our study, we interview change makers who seek to drive change for biodiversity protection. Our aim is to expand the understanding of the cognitive struggles and reflections that the participants of the issue field experience as a part of their change efforts. The main research question addressed in this study is as follows: How do individual change makers manage the uncertainty in the interstitial issue field? We interviewed 27 change makers who address biodiversity in their organizational roles and proactively seek to create engagement and change to safeguard it (Sonenshein et al., 2014). These individuals represent organizations from three sectors: key government agencies, NGOs, and private sector firms. They jointly participate in regenerative organizing in this interstitial issue field, and they all face uncertainties that increase 
the difficulty and demands of their efforts (Sonenshein et al., 2014). These uncertainties invoke reflexivity or, in other words, silent internal or external conversations that help change makers calibrate their courses of action (Archer, 2007).

Overall, our study draws attention to the role that the reflexive processes by individual change makers operating in uncertain and cognitively demanding settings play in change efforts around grand challenges and the issue of biodiversity, in particular. Our main contribution, a theoretical model, draws attention to the interface between an individual's internal and external processes by bringing together (internal and external) reflections and the courses of actions they influence. In doing so, our study advances knowledge of how change makers can manage uncertainty, convey the difficult issue of biodiversity to others, and promote engagement for its protection.

\section{LITERATURE}

\section{Biodiversity and initiatives}

Biodiversity (or biological diversity) has radically declined during the past 50 years globally (WWF, 2016). Indeed, the planetary boundaries are already exceeded for biosphere integrity (or biodiversity loss), which is a critical earth systems process (Steffen et al., 2015; Whiteman et al., 2013; Kolbert, 2014, 2018). In the area of genetic diversity, the losses surpass the zone of uncertainty into the high-risk area, whereas in functional diversity, the precise boundary remains unknown (Stockholm Resilience Centre, 2018). Biodiversity loss is mainly driven by the growing demand for food, water, and other resources (Stockholm Resilience Centre, 2018). This demand is associated especially with the size and growth of the human population, rising standards of living, unsustainable consumption and production patterns, and technological change (Crist et al., 2017; WWF, 2016). Furthermore, biodiversity loss is amplified by climate change - the 
increasingly hot and dry climate has caused the mass deaths of pines and beetles in the Rocky Mountains in North America, for instance. Because biodiversity loss is influenced by the interactions of multiple global megatrends, one cannot link it to clear sets of causes and solutions, but one can sense increasing dangers around the corner.

Halting or even slowing down biodiversity loss demands decisive action by individuals, firms, NGOs, and governments. National governments and the United Nations Environment Program responded to the declining trends in biodiversity at the 1992 Earth Summit in Rio de Janeiro by establishing the CBD (CBD, 2005). Later on, members have made more specific commitments toward the Convention's implementation, the Aichi targets, and related initiatives, such as the Sustainable Development Goals (CBD, 2014; Ministry of the Environment, 2014; United Nations, 2015). At the regional level, the EU has adopted the EU Biodiversity Strategy, which aims to halt the loss of biodiversity and ecosystem services within the EU and to help stop global biodiversity loss by 2020 (EU, 2011). However, the mid-term review of the strategy in 2015 notes that more needs to be done at the grassroots level to translate the EU's policies into action (EU, 2015).

In Finland, the government has drawn an ambitious biodiversity action plan (Ministry of the Environment, 2012) that affects multiple business sectors. The overall targets are considered ambitious and implementation demanding; as a result, the plan has caused worry and opposition among private actors, such as forestry and agricultural firms, because of their diverging (economic) interests. Recently, the government has begun not only using legislative action but also increasingly pushing for corporate and civil society engagement to bring about large-scale changes and transformation across sectors (also see Le Ber \& Branzei, 2010; Ritvala \& Salmi, 2010; Hahn \& Pinkse, 2014; Quarshie \& Leuschner, 2018). Specifically, to complement its (existing) forestry- 
related programs and nature education activities, the Ministry of the Environment started to fund a new biodiversity program called Business and Biodiversity, which is targeted at major companies from various industries. It is organized by key government agencies in collaboration with a leading corporate sustainability network in Finland. This program seeks to diffuse best practices related to biodiversity management among the business community, and the actors involved form a part of the interstitial issue field where we study regenerative organizing.

\section{Interstitial issue fields and agentic individuals}

Actions to address grand challenges, such as biodiversity loss, require changes in societies and institutions. The institutional literature has devoted increased attention to establishing how organizational fields and structures change rather than how they stay the same (Greenwood, Suddaby, \& Hinings, 2002; Fligstein, 2013; Zietsma et al., 2017). Institutional field studies have examined, for instance, the roles that actors, such as institutional entrepreneurs and field incumbents, play in these processes (van Wijk et al., 2013; O'Mahony \& Bechky, 2008; Maguire, Hardy, \& Lawrence, 2004). Increasingly, a significant change in these fields is viewed as resulting from collective action or the interactions between peripheral and established actors in the field (Van Wijk et al., 2013; O'Mahony \& Bechky, 2008; Zietsma \& Lawrence, 2010).

We investigate the actions and interactions between actors who are members of different fields but have an interest in the same issue of biodiversity. Following Hoffman (1999), we approach biodiversity protection (in Finland) as an issue field (or arena). It brings together “actors who have commitments to, and embeddedness within, very different institutional logics and structures, suggesting a field that is by no means settled or uniformly constraining" (Ziestma et al., 2017, p. 394). Interest in the biodiversity issue creates interaction in an interstitial space between existing fields (Furnari, 2014). The emerging interstitial issue field includes members 
from exchange fields and issue fields (Zietsma et al., 2010), who bring along very different logics into the emerging field. Yet, they come together with the aim of negotiating and coordinating in order to find a response to the issue. The important characteristics of an interstitial field, therefore, are actors' embeddedness (within their own field), the coexistence of multiple logics, and actors' joint interest in the issue, which is necessary for collaboration and change to take place.

To understand institutional change and field emergence, one needs to grasp the infrastructure of the field. According to Ziestma et al. (2017), the boundaries of an interstitial field are permeable, and the field brings together very different parties, as is also evident in prior studies. For instance, Granqvist and Laurila (2011) analyze the emergence of the nanotechnology field, which includes scientists, government officials, entrepreneurs, and activists, whereas Maguire et al. (2004) describe the emergence of the HIV/AIDS field, which brought together actors, such as pharmaceutical firms, patient care advocates, physicians, and members of the gay population. These differing actors bring their various - even competing — interests with them to debates over issue interpretation (Hoffman, 1999). Furthermore, members' field positions are in flux. Granqvist and Laurila (2011) show how internal hierarchies within communities are challenged by peripheral influences. Zietsma and Lawrence (2010) investigate the interplay between insiders (forest companies and Ministry of Forests) and outsiders (e.g., environmentalists) in an institutional change on forest practices. Indeed, a legitimate position (i.e., organizational role as well as individual characteristics) increases actors' potential for agency in institutional changes (Maguire et al., 2004).

While interstitial issue fields are primarily viewed to bring together organizations, the interacting and agentic individuals within organizations play a key role in internalizing (shifting) conditions and in instigating change. Indeed, Purdy and Gray (2009), who studied a 
regulatory change in a field, stress the need for multilevel investigations to count for both the impact of institutional constraints and human agency on field evolution. They note (2009, p. 376) that "new logics are transmitted by individuals (institutional entrepreneurs), enacted as new organizational practices or as new organizations, but ultimately ratified by existing institutions."

Prior research on interstitial issue fields has generally taken a broad approach, investigating extensive field changes over long periods. Examples of such studies include Ziestma and Lawrence's (2010) examination of conflict over harvesting practices and decision authority in the British Columbia coastal forest industry from 1985 to 2006, Granqvist and Laurila's (2011) investigation of the emergence of the US nanotechnology field from 1986 to 2005, and Hoffman's (1999) study of corporate environmentalism in the US chemical industry from 1960 to 1993 . While these studies present several conflicting issues and problematic debates, we suggest that the scope of grand challenges makes them even more difficult to tackle in practice. They are critical for the planet and for humankind, and they call for solutions that seem to be out of reach of any individual actor. Moreover, biodiversity loss is an increasingly difficult and emotionally demanding issue.

In effect, our empirical findings suggest that knowledge problems related to biodiversity protection manifest themselves not only as uncertainty, complexity, and ambiguity but especially as equivocality (Townsend et al., 2018, p. 672), meaning that in the field, multiple meanings and interpretations of the (biodiversity) issue exist, which differ from each other. Sustained collective equivocality is therefore a special characteristic of the interstitial issue field of biodiversity protection. Moreover, the field identity concerning biodiversity preservation is ambiguous and emerging, and multiple, fragmented logics are in place. For individuals, the flux in actors, roles, and callings creates uncertainties that add to the cognitive challenges and emotional demands that individuals in interstitial fields face. Indeed, the uncertainties and equivocality need 
to be internalized by change makers, while everything else changes in the field as issues unfold, so the individual change maker represents a suitable focus of investigation.

\section{Reflexivity}

As discussed earlier, biodiversity loss (or protection) does not fall conveniently into a cause-effect model; equivocality confounds change makers and other actors in an emerging interstitial issue field. In a recent study, Suddaby et al. (2017) point out that the over-rationalized understanding of institutional actors contributes to our inability to explain actions.

Reflexivity is one of the key constructs to counterbalance the over-rationalized understanding of human behavior (Suddaby et al., 2017). Specifically, people should be viewed as active agents capable of self-reflection and exercising governance in their working lives (Archer, 2007), as well as engaging with other individuals to "form collective intentions to engage in institutional actions" (Suddaby et al., 2017, p. 7). Reflexivity means a person's "general awareness of the constraints and opportunities created by the norms, values, beliefs and expectations of the social structures that surround them" (Suddaby et al., 2016, p. 229). Archer $(2000,2007)$ argues that intra-subjective conversation is a key element of social action. She defines reflexivity as "the regular exercise of the mental ability, shared by all normal people, to consider themselves in relation to their (social) contexts and vice versa" (Archer, 2007, p. 4). Researchers recognize that individuals can gain moments of self-awareness and clarity on the constraints they face especially during crises and field tensions (Suddaby et al., 2016). In these instances, they deliberate and ask themselves (or others) questions, such as the following: What am I trying to accomplish? What should I do next to achieve it? (Archer, 2007, pp. 2-4). This ongoing effortful conversation (within one's own head or with others) is important because it influences one's future course of action. Agentic reflexivity therefore mediates between the structurally shaped circumstances that 
individuals confront and the courses of action they take in response to these conditions in light of their (constellations of) ultimate concerns (Archer 2007, p. 16).

In the context of this study, we submit that because change makers face equivocal interpretations of biodiversity (loss and preservation), silent conversation is a natural reflexive process for them to make sense of their undefined tasks and to process their thoughts and emotions. The loss of biodiversity causes so-called solastalgia or the pain experienced when there is recognition that the place where one resides is under immediate assault (Albrecht et al., 2007). Reflexivity, consequently, serves as a practical and relevant starting point in understanding how engagement and change toward biodiversity protection may take place, specifically how change makers manage equivocality through (internal and external) conversations and how this reflexivity influences their actions.

\section{METHODOLOGY}

\section{Research context}

In this study, we use a qualitative research approach to investigate the reflections by participants of the biodiversity protection interstitial issue field (Zietsma et al., 2017; Sonenshein et al., 2014; Schabram \& Maitlis, 2017). Our empirical data were collected in Finland, which is one of the early adopters of international biodiversity initiatives and one of the first countries to sign the CBD agreement, which entered into force in 1993 (Ministry of the Environment, 2018). This is a unique context to study biodiversity protection because the level of scientific and societal ecological knowledge in Finland is high compared with that in other countries (e.g., Hanski, 2016), the country's legislation related to biodiversity is among the most detailed and advanced in the world, and Finns typically have a close relation to nature (Ministry of the Environment, 2014). Moreover, the country engages actively in biodiversity protection efforts. In accordance with the 
Aichi targets of 2020, the Finnish government developed its 2012-2020 Saving Nature for People national strategy and action plan, which replaced the earlier biodiversity strategy the country had. The new strategy includes the goal of halting biodiversity loss in the country by 2020 and is meant to be implemented by government actors, civil society groups, and stakeholders (Ministry of the Environment, 2014) (see Figure 1). Business engagement (beyond the traditional forestry actors) is an important part of the action plan, and the country has joined the Business and Biodiversity network of the CBD as one of the 21 national or regional actors (CBD, 2018).

Figure 1 about here

To implement the national plan, which involves inducing large-scale changes and transformations within the business community, the Finnish government signed a partnership agreement in 2012 with a leading corporate sustainability association regarding a biodiversity training program. Since 2014, the association, Finnish Business \& Society (FIBS), has organized training programs and events to educate and diffuse best practices related to biodiversity management among the business community (see e.g., FIBS, 2015). Specifically, it organizes (together with government partners) an annual biodiversity training program, which was first called the Biodiversity Master Class (in 2014, 2015, and 2016) and later the Natural Capital Training Program (in 2017 and 2018). It also organizes seminars and workshops, as well as publishes guidebooks on the topic of managing biodiversity, in addition to other sustainability and responsibility topics. These activities are important for building awareness and for legitimizing and incorporating biodiversity into the agenda of companies and other actors. The participants of these Business and Biodiversity program activities provided us an initial sampling frame and an entry point into the interstitial issue field where we could study our initial focus-interaction and action for biodiversity protection. 


\section{Interview data collection and sampling}

All of the informants for the study were involved in actions and interactions in the interstitial issue field of biodiversity preservation in Finland. We began selecting them from the initial sampling frame of the biodiversity program based on theoretical reasons (Patton, 1990), which meant sampling individuals who were actively striving to engage business and other actors in biodiversity protection. The first informants participated in FIBS' Business and Biodiversity program activities as seminar or training program participants, organizers, trainers, speakers, or competition jury members. We sought to include various types of field participants, including government agencies, NGOs, and private sector actors. The purpose was to capture competing motives, interests, interpretations, and understandings of biodiversity (and other sustainability issues), in addition to a variety of actions and interactions. In addition to the biodiversity program activities, the individuals were involved in other corporate social responsibility (CSR) initiatives of their organizations and overlapping issue fields.

As the interview data collection proceeded, we broadened our sample by including additional organizations and informants who were not directly involved in the Business and Biodiversity program but were otherwise central actors in the issue field. This was done to decrease sampling bias and ensure that we could better capture the phenomena of interest (also Schabram \& Maitlis, 2017). We used snowball sampling procedures (Patton, 1990, p. 182) and asked all interviewees to suggest additional informants on a broad front. They were asked to suggest (from different sectors) organizations that were involved in the issue field of biodiversity protection in the context of business, organizations that were or should be otherwise active around the issue, and individuals who dealt with the issue as a part of their jobs. This sampling strategy that sought 
various types of informants across three sectors ensured greater completeness in the overall sample.

Altogether, we conducted 27 semi-structured interviews, lasting for 73 minutes, on average (from 50 to 135 minutes). Table 1 illustrates the sampled organizations and interviewees. The final sample of organizations includes three government agencies, seven nonprofit organizations or associations, and 17 private companies. The government agencies can be further classified into ministries and government institutes, whereas the nonprofit organizations include environmental NGOs, sustainability-related associations, and (industry) trade associations. The sampled private companies operated in various industries, including food (e.g., manufacturing, retail and restaurants), consumer goods and services (e.g., ICT, banking and insurance), forestry, construction and maintenance, and heavy industry. Some of the organizations were key participants of the biodiversity issue field for several years, whereas others became aware of the issue and joined the field only recently - in many cases, following the example of the companies that took part in the first trainings. In emerging issues, such as biodiversity protection, the time spent on the issue matters (see e.g., Sonenshein et al., 2014). Overall, in our sample, we achieved variance across two dimensions: the kinds of organizations involved and the exposure of the organizations to biodiversity loss (and protection) in their activities.

Table 1 about here

All individual participants in our study can be characterized as specialists, managers, or directors/executives. All of them dealt with biodiversity, natural resources, environmental issues, cross-sector partnerships, sustainability, and/or CSR-related issues as a part of their work. These terms were explicitly incorporated in the titles of 21 informants, whereas the other participants' main tasks included quality, development, or project management, as well as general 
or top management duties. Many informants focused significantly on biodiversity protection issues in their work role, whereas for others, it represented one among many sustainability issues.

The lead author was present at all of the interview events, whereas the second author participated in nine of them. The main themes discussed during the semi-structured interviews concerned the relevance of biodiversity to the organization and the informant's work, organizational activities and practices used to address biodiversity loss, the meaning and importance of biodiversity to the informant personally, collective actions and interactions in the issue field, and the results of organizational and collective actions and interactions. We slightly adapted the interview questions based on the context of the interviewees. As our data collection proceeded, our focus shifted more to emerging findings related to reflections. The informants' silent conversations related to managing equivocality in the interstitial issue field were prevalent in our data even though they were not been our study's original focus. Therefore, we began asking additional questions regarding the informants' personal (cognitive) processing of biodiversity and other information, as well as questions related to the competing logics, meanings, and interests in the field.

\section{Archival and field data collection}

During the entire research process, we also systematically collected archival data, which include presentation materials from the biodiversity-related field events we attended; biodiversity-related publications, websites and media materials produced by FIBS; company CSR, sustainability and annual reports, websites, and other documents; Finnish government (nationallevel) strategies, reports, plans, and policy documents; and NGO reports and other documents (see Table 2). The archival data totaled 112 documents, and they were examined during the data collection and analysis stages. Some of the materials provided us direction in the research design 
and interview stages, whereas others were examined in greater detail in the analysis and theorization phases. Overall, the archival data particularly contributed to our understanding of how companies are trained on the issue of biodiversity; how they and other actors operationalize, communicate about, and respond to the issue; the commitments and plans the government has made to address the challenge; the progress made to date; and the broader institutional, environmental, and social contexts of our study.

Table 2 about here

We also attended field events related to biodiversity protection in Finland (see Figure 1) before and during the main (interview) data collection stage. The field events we attended before the beginning of our study (in 2015-2017) included the CBD Business and Biodiversity Forum in Helsinki in 2015, multiple FIBS biodiversity and sustainability seminars, a corporate biodiversity competition organized by FIBS, and an academic biodiversity-related conference. These events contributed to our understanding of the main actors, activities, and field change processes in our empirical context, as well as helped us design and launch our study. During the main data collection stage in 2018, we attended one biodiversity-related seminar and two full-day training events organized by FIBS, as well as one academic seminar held at a major university and directed mainly to environmental scientists. Detailed notes were taken in all the events and were added to our research database.

Event observation and participation during the data collection stage especially contributed to our understanding of how company managers are trained on the issues of biodiversity loss and preservation; how these trainings are organized and who participates in them; and how they are received by the managers. The academic seminar also improved our understanding of the types of research topics and issues that environmental scientists deal with in 
this context, of the detailed nature of their knowledge, and of the siloes that exist between the scientific community and other actors that deal with the issue in this empirical context.

\section{Data analysis and theory building}

All interviews were conducted in Finnish, the native language of two of the investigators and the informants. All informants gave us permission to audiotape the interviews, which were transcribed and translated into English for data analysis. The 27 tapes amounted to 333 single-spaced pages of transcripts, which were then analyzed and coded. The first and the third author independently coded the data to search for recurring themes in the transcripts. As noted, the informants' ongoing conversations related to biodiversity were not our focus to start with. Rather, the topic emerged from our interview data through induction, and we then started specifically coding the data for the informants' reflections related to the uncertainty that is present in the field and in the work related to biodiversity, silent conversations about the issue of biodiversity, and the impacts that these reflections had. Our focus began shifting to reflexivity among individuals in the face of equivocality, and how the respondents engaged with the equivocality.

In our theory building effort, we mainly used an inductive approach to generate new insights into and a theoretical understanding of individual engagement in biodiversity preservation (Bansal, Smith, \& Vaara, 2018). In practice, we started with the general aim of investigating how actors address the topic of biodiversity protection in Finland, and we moved to ongoing silent conversations by individuals; we found that these emerging empirical findings related to existing theoretical understandings on reflections and equivocality (e.g. Archer, 2007; Townsend et al., 2018). It appears that in the interstitial issue field, which involves cognitively demanding work and solitary tasks, informants indeed often engage in deliberation (see Archer, 2007). In particular, in our study context, which is imprinted with equivocality-including the persistence of multiple 
interpretations of the severity, relevance and meaning of the biodiversity issue - the change makers appear to continuously have such internal and external conversations. In the findings that follow, we first describe the reflections that the change makers had on biodiversity in the course of their efforts, and then explain how these ongoing effortful conversations affect their actions in influencing the issue field and managing equivocality within it. Finally, our theoretical model brings together the change makers' reflections and ensuing actions.

\section{FINDINGS}

\section{Silent conversations on biodiversity loss}

The individual change makers of our study faced considerable equivocality in the biodiversity protection field during their change efforts, which invoked reflexivity or silent conversations. Our data suggest that the interviewees have such reflections related to the issue itself, as well as the attempted change efforts. These reflections manifest themselves as internal and external silent conversations that help individuals to make sense of the equivocality (or other knowledge problems) they face (Townsend et al., 2018), and to refine their actions aimed at creating engagement with the issue (Archer, 2007). The informants' biodiversity interpretations can be viewed almost as a continuum, where at one end are somewhat ambiguous or biological views of biodiversity as the state of the planet, or as species and habitats that are in grave danger (see Table 3). At the other end, biodiversity is interpreted as merely a source of business advantage or, at worst, as a basis for greenwashing.

Table 3 about here

In the following sub-sections, we focus on the three main areas of silent conversation related to biodiversity that emerged from our data. The first area concerns the magnitude and urgency of the challenge, and these reflections were activated especially because of the change 
makers' efforts to clarify to themselves what they personally thought about the biodiversity trends and indicators, in the absence of objective answers (Weick, 1979). The second area relates to the relevance of biodiversity to one's organization, and these reflections allowed the informants to make sense of their employer's (often unclear or equivocal) biodiversity impacts and interdependencies. Finally, the third area concerns the meaning of and one's interpretation of the biodiversity concept. In this area in particular, the respondents faced significant equivocality, as multiple meanings and interpretations of the issue existed - and persisted collectively among actors of the field over time (Daft \& Macintosh, 1981). Through reflection, the informants sought to make sense of how they (and others in the field) understood the issue. Next, we describe the three areas of silent conversation in detail, and then we explain how these reflections influenced the change makers' courses of action.

Silent conversations on the urgency and magnitude of the issue

Our data suggest that the level of biodiversity knowledge among (environmental) scientists in Finland is among the highest in the world, but even the topic area experts whom we interviewed struggled to grasp the urgency and magnitude of biodiversity loss. Despite their educational backgrounds, their work positions related to biodiversity or sustainability, and their advanced understanding of environmental problems, many informants carried on internal (and sometimes external) conversations about what all the biodiversity indicators and downward trends meant. Many witnessed the changes in landscape and biological features of places in Finland based on their personal experience. However, several informants brought up silent conversations related to whether we were already nearing a tipping point where a severe crisis would escalate or whether they were being blind to the actual scope and urgency of the biodiversity grand challenge. A consensus emerges from the interviews that biodiversity will surface in public discussions as a 
mega trend soon, and many informants thought that a real crisis may be imminent. The following quotes illustrate these issues and the informants' reflections:

"That's the thing because biodiversity is ... as in the [seminar event] at [organization], they used these different visualizations [of biodiversity loss]. And if you think about children's game Jenga, which block you dare to remove? You have certainly heard the example of how many bolts you dare take off from an airplane if you need to still fly it.” (Director/Executive, Nonprofit 04)

"[Global warming over the next 50 years] also means a total change for biodiversity, and we can no longer compare it to the situation 50 years ago, as we do now. In my view, almost no one has this type of understanding because everyone shares the illusion that climate change will be stopped. This problem in people's thinking is everywhere; in fact, in 2017, some people began to realize that this is the case. If I say that even $90 \%$ or $80 \%$ of experts and researchers do not understand that this will happen ... and when they don't understand it, they are also unable to think that ... now, if we compare our species to the state when nature assessments began in the 1950s and 60s and the information we have available since then ... and from then on, we contrast which species have increased, which have decreased, and which have disappeared-332 species have disappeared. So, if we continue in the same way, as we will, according to IUCN criteria, then we cannot compare them. And then there is the fact that species migrate here. In the 2000s, over 1,000 species have migrated to Finland. Okay, the majority of them have not yet established permanent populations, but they will. So what do I compare these with? Species that are capable of dispersal migrate here; moths and birds are good examples. Or the jackal, which is coming. Then we have species that are capable of living in many different types of habitats, let's say these types of omnivores that take advantage of their environment or are opportunists. But all the plants from Central Europe to the Baltic Sea, there is no hope in 50 years when, for example, the spruce is, even after 10,000 years, still spreading toward the north, a few centimeters per year, or what was it, 20 centimeters a year. I don't see anyone thinking about 
how I can compare biodiversity [to past levels] in 50 years. Even in my head, I cannot compare it.” (Specialist/Counsellor, Government 03)

These quotes highlight key facets of equivocality: that no certain answers exist in relation to the grand challenge of biodiversity, despite the ample amount of precise biodiversity information available in our empirical context to the sensemakers (Townsend et al., 2018; Daft, Lengel, \& Trevino, 1987; Weick, 1979). This is because nature takes its course and continues to surprise the actors of the field. Further, the quotes illustrate that it is through ongoing effortful conversation within their own heads (or with others) that the key change makers try to process the available information and to clarify to themselves what they personally understand and think about the urgency and magnitude of the challenge, even if others around them fail to acknowledge or comprehend the situation.

Silent conversations on the relevance of biodiversity to one's own organization

Another topic that the informants reflected on was the relevance of biodiversity to one's own organization. While this question is posed at the organizational level, it explicates the context of the individuals when reflecting on the issue. Since we selected interviewees based on their organizational role and task, their silent conversations about their own organization's biodiversity connections become relevant to our study. Across our sample, there was considerable variance in how critical and relevant biodiversity actually was to the informants' organizations. Many of the NGO, government agency, and firm representatives we interviewed worked for organizations that had biodiversity and/or nature protection closely integrated into their purpose, mission, and overall strategy. Other informants worked for organizations that did not have a significant exposure to biodiversity. Especially for many firm managers whose organizations did not produce or source natural raw materials (e.g., service firms), grasping the relevance of biodiversity to their organization was a challenge. While forestry company informants had a 
detailed understanding of the interdependencies and impacts that their companies had (partly because of the history of biodiversity regulation and voluntary action in their industry), interviewees from most other sectors experienced great difficulties in associating:

"And maybe it's easy to think about it in such a way that if we were a forestry company, that would be directly a part of our business. A forestry company [manager] is forced to think about conserving biodiversity, at least on some level. Of course, if you cut down forests, you destroy biodiversity, I guess. Then, you have to aim at renewing it so that your business can operate continuously. In our case, [the connection] is indirect. Except of course through this equipment and through the effects of our supply chain.” (Director/Executive, Firm 17)

"The topic itself is not difficult [in investment discussions with company managers] ... perhaps other issues are just more easily measurable, and that is why it is natural to start from them. For example, if the regulations on carbon dioxide emissions for energy companies become stricter, those figures are easy to calculate. In addition, the threat of regulation is an easy subject that can materialize for investors. That is one. It may come through [the issue of] chemical safety or toxic emissions. You can also talk about it by using other terms because biodiversity is a bit ... maybe similar to one not often using the term 'human rights'; you instead talk about occupational safety and such sub-themes." (Manager, Firm 20)

Here, the reflexive processes and varied conclusions drawn by firm representatives accentuate the equivocality of approaching the issue of biodiversity preservation. In practice, many factors seem to hinder individuals' understanding of how their organization is related to biodiversity. In addition to the abstract nature of the biodiversity concept, biodiversity loss is hardly detectable even for experts or those who are directly in touch with or spend time in nature. Furthermore, many of our informants reside in the downstream of global supply chains, where spatial and temporal lags exist between the causes (e.g., consumption) and impacts (e.g., in raw 
material production) of biodiversity loss. In some cases, the informants could easily observe some of the connections to biodiversity, but not for others. The latter could happen, for instance, in the case of managers whose companies operated or sourced their products primarily in built environments where nature also existed (also Cohen \& Muñoz, 2015).

Silent conversations on the interpretation of the concept

Many interviewees deliberated and tried to reach a conclusion (Archer, 2007) about how they actually understood and interpreted the issue and concept of biodiversity. Most thought that the original English concept and its Finnish translations meaning "biodiversity" and "nature's diversity" (in Finnish "biodiversiteetti" and "luonnon monimuotoisuus", respectively) were abstract and difficult for ordinary people to grasp. Even those who thought that the terms were, in principle, self-explanatory, found it difficult to talk about the topic with others who often had a vague understanding of the issue:

"I would say that for us, it's nature's diversity or biodiversity, but I recognize that it seems to be a surprisingly difficult definition for people — what it means. We need to find new ways of describing it so that people understand what it's about. We talk about the diversity of nature or biodiversity ... It's the diversity of species and the diversity of habitats. I don't think that people are able to define it that way. Maybe people can perceive it means that nature is doing well or something like that. It probably requires examples.” (Director/Executive, Nonprofit 04)

Overall, most informants reached a relatively clear understanding of what biodiversity means to them based on their deliberations. However, collectively, there is no single interpretation or agreed-upon meaning, as the multiple interpretations differ from one another (Daft \& Macintosh, 1981) and clearly represent equivocality (Townsend et al., 2018; Zack, 2001). In our study context, when an individual resolves his/her own equivocality, the resulting interpretation may add to the collective equivocality of the issue field, because the resulting 
interpretations differ starkly and new meanings continue to surface due to the flux of the actors and trends. Indeed, it appears that many informants have internalized the vast range of interpretations available and are torn among them, as well as concerned about how the issue will be interpreted by the various actors in the field in the future. In the presence of this persistent and (collectively) increasing equivocality, more information about the issue or further deliberation by such actors does not help define biodiversity and settle the field (Townsend et al., 2018). Table 3 about here

Closely related to the spectrum of interpretations, many informants felt that especially when species and ecosystems or habitats were emphasized, getting the worlds of biodiversity and business to meet was difficult. This, in their opinion, caused problems for managers in understanding, approaching, and addressing biodiversity-related issues in their work:

“...let's put it this way that traditionally, it's thought [on the consumer side] that 'building museums' is protecting; in other words, the forest is protected, and no one can touch it, and, thus, the world will be saved. However, that is not how you save the world. Companies that do good and green businesses save the world." (Manager, Firm 13)

Indeed, the challenges that business managers and other individuals experienced in interpreting the concept and applying it to businesses also affected the content and name change of the government-sponsored corporate biodiversity training program. After the first few years, the training course was adapted to better incorporate the notions of ecosystem services and natural capital, which were considered to be concepts that would be easier for managers to adopt and to apply in their work. Originally, the training was called the "Biodiversity Master Class," but the name was changed to "Natural Capital Training." Through the redesigned program (Archer, 2007), the new understandings could be applied and reinforced. 
These changes in the program further stimulated internal and external conversations on biodiversity. While many actors actively used the new business-focused concepts, which added new interpretations of biodiversity to the issue field, other informants brought up that they disliked them or the added emphasis that such terms placed on the economic value of nature. The terms were considered especially incompatible when communicating with stakeholders who did not represent the business sector:

“We haven't used [natural capital]. I've personally thought about it; I'm not quite sure whether it's good or bad that companies are, of course, interested in economic aspects, but when you always liken it to money, it is, I think it's a really difficult question ... Somehow, it feels like that's how you get attention to it in the company management, but that always emphasizes the economic aspects instead of considering that ... It's really quite a big problem for us all. You should look at the money all the time. I think it's a bit difficult concept to think about, whether it's good or bad. Maybe it depends on the context." (Manager, Nonprofit 05)

"I do not really like [natural capital]. To me, it's about the economy. It makes me think of a balance sheet. My own perceptions lead to that ... If you think about natural capital, it comes from economics. Nowadays, there's a lot of discussion about the ecosystems of [IT firm], but it has nothing to do with the actual ecosystems, it has been taken elsewhere. Natural capital is sort of similar. It is not easy to define — so what would be something that people would understand?"

(Director/Executive, Nonprofit 04)

Overall, the challenges in understanding and talking about biodiversity, as well as the multitude of interpretations that existed among the informants, suggest that within the broader institutional field, there is no single definition and meaning that would be understood and could be applied more generally; instead, there is a plurality of them. Moreover, the reflections that 
informants continuously have on the issue suggest that biodiversity protection easily becomes an existential quest to those trying to engage others in it.

\section{How the reflections influence change makers' courses of action}

From our data emerged three sequential and iterative actions by individuals, which relate to the three areas of silent conversation by the change makers that we discussed above. We call these actions as filtering, modeling, and translating (See Table 4), and we explain them in greater detail below.

Table 4 about here

Filtering

One key area of silent conversation discussed above concerned the magnitude and urgency of the issue, which related to the difficulty for even experts to grasp how challenging a problem biodiversity loss was and would become in the future. Many informants, particularly the topic area experts, seemed to have developed relatively pessimistic views of the current state and future developments concerning biodiversity globally. Indeed, several informants mentioned that crises and collapses would likely begin to happen in the near future. Subsequently, many of the governmental and nonprofit organization informants felt that they could not reveal how ugly the entire picture was to the managers and other field participants they were trying to influence. As one government informant explained,

“... of course I cannot tell [company managers] like I can tell you that we have already lost this game

... I can tell them, but I could never tell them how things really are - that would only paralyze people."

We label the group of actions they took as filtering - meaning that change makers screen, remove, or select information on biodiversity when conversing with other individuals inside or outside one's organization. Indeed, in talking about biodiversity (loss) with firm 
managers, many change makers felt compelled to focus on the positive, strike a positive note, or otherwise try to ensure that people became enthusiastic rather than pessimistic or paralyzed (see Table 4). Evidently, the ample availability of indicator data (Townsend et al., 2018) and the current and projected future pace of biodiversity loss globally make the problem feel insurmountable, and any action and change efforts by individual actors seem negligible. It was clearly a taxing task for many of the change makers to determine how the right balance can be achieved between the worrisome facts and rhetoric and the more cheerful calls to action.

\section{Modeling}

The challenges and equivocality that individual managers experience in trying to relate biodiversity to their organization call for concrete examples of practices, tools, and best practices. This is the second action-modeling. It refers to the process in which change makers present best practices, cases, and other solutions to one's own and other organizations. Key change makers help managers and other actors understand the relevance of biodiversity to their respective organizations by relaying information concerning various types of challenges and practices in other organizations and their solutions, tools, and guidebooks. Some of these solutions were applicable to broader varieties of companies across different sectors, whereas others were very specific, such as the development of sustainability and biodiversity indicators or instructions on the application of environmental, social, and governance (ESG) factors in the finance sector. Such information makes organization managers aware of shared challenges, thus making biodiversity a less intimidating topic.

Furthermore, case presentations are given by experts and past participants of the training program. The examples help managers understand their organizations' interconnections and interdependencies with nature. The examples unproblematize biodiversity by presenting it as 
a common challenge to all and as an integral part of one's social and environmental responsibility. In other words, by contextualizing and interpreting what the key biodiversity connections could be, change makers bring temporary suspension of equivocality for their target audience. Indeed, the presentations enable audiences to benefit from the results of reflexivity by the persons doing the modeling, which may facilitate the observation of the impacts and interdependencies that their own organization has. Numerous speakers from various industries and learnings from peers were incorporated in the government-sponsored biodiversity training program and other events taking place in the field. Company speakers and their case studies were considered by many participants as one of the most useful aspects of the program, and all company informants stated that their companies benefited from the experiences and knowledge of other private actors in seeking to address the biodiversity issue.

\section{Translating}

Many informants experienced continuous silent conversations regarding how they interpreted biodiversity over time as they learned about the issue and sought to figure out what it meant to their respective stakeholders. Talking about biodiversity with various internal and external stakeholders, including customers and the public, work colleagues, and (firm) top management, as well as investors, emerged as problematic for the informants. Indeed, the general lack of understanding of what biodiversity and related terms meant seemed to be a major obstacle to the informants' efforts to drive change.

Interestingly, it emerged from our data that most of the informants were adapting the way they spoke about biodiversity to others, depending on the circumstances and context involved (Table 4). The high equivocality they encountered did not help the actors reach a consensus on a single meaning of biodiversity and pursue corresponding actions. Rather, the equivocality 
compelled many change makers to frame biodiversity in specific languages and to use vocabularies that resonate with their respective audiences. We call this third action translating - a strategy of change makers to frame the biodiversity issue in the context of the targeted organizations and individuals and to paraphrase it in the language of the corresponding audience. This implies that the concept of biodiversity was articulated to others in a context of other connected ideas, concepts, and actors, and the concept was subject to continuous change and adaptation. Specifically, the language that worked with the public was not necessarily considered suitable for communicating and interacting with managers or investors, and, hence, the informants often needed to adapt the words into the language used by the audience.

Some of the key change makers used a broad variety of meanings and interpretations of biodiversity in their work and change efforts, and they applied these based on their audience. For example, one change maker explained that he/she thought that the talk and details about species go over the top with ordinary people, and, instead, they would talk about nature and its preservation more generally with the public. At the same time, the same change maker adapted his/her language when dealing with company managers and leaders and fluently spoke their language.

As mentioned, many informants found it particularly challenging for firm managers, top leadership, and investors to understand and apply concepts, such as biodiversity, in their work because the term is too biological and disconnected from the business and finance worlds. The use of alternative terms, such as ecosystem services, was encouraged by many informants to make the issue more understandable and applicable for managers. Indeed, the concepts of ecosystem services and natural capital were even integrated deeply into the biodiversity training program over the years (as reflected in the new name of the program, too). While some change makers had reflected on the concept of natural capital and decided that they did not embrace it, others had 
arrived at the conclusion that it could aid business managers' understanding of the different types of values and benefits offered by biodiversity and could help them address and take action for biodiversity.

This need to understand the culture and speak the right language with the people one is trying to influence came up unprompted in multiple interviews and suggests that many change makers had internalized a broad spectrum of meanings (Table 3) and could reflexively move, as needed, from one end to another in the course of their efforts (Archer, 2007). Proper language and terminology, rather than more information about the issue as such (Townsend et al., 2018), seem to help mitigate equivocality.

\section{Theoretical model}

In this sub-section, we propose a theoretical model that brings together the three areas of silent conversations related to biodiversity and the three actions by change makers that emerged from our data. The reflexivity that the individuals continuously engage in, as well as the three iterative actions of filtering, modeling, and translating, jointly form a recursive process that individuals keep cycling through in the course of their efforts in the biodiversity protection issue field (see Figure 2) ${ }^{1}$.

Figure 2 about here

As Figure 2 shows, the informants engage in filtering not only in their own minds but especially in transmitting information to others as a part of trying to engage them in biodiversity protection efforts. By modeling, change makers, together with their peers and other actors in the field, seek to adjust and settle their understanding of biodiversity's interlinkages with their businesses and ways to protect it. Finally, actors' internalization of a continuum of

\footnotetext{
${ }^{1}$ We are grateful for the helpful comments provided by the guest editors, which have helped us to further develop our theory.
} 
biodiversity interpretations, as well as a growing certainty of what it is not (e.g., greenwashing), allows the translation of the issue to the varying audiences' languages as a part of the efforts to create engagement. The overall process that involves individuals engaging in existential reflexivity, way beyond their work role, and cycling through the three constructs in the recursive process is illustrated by the following quotes (and Table 4):

“... I've noticed that [managers from] different companies think about this topic in very different ways. And now that we think about what we should be thinking about, in my opinion, we should be thinking about the impacts of these ecosystem services ... [That concept] was first introduced to make people understand why biodiversity matters. And that's why I think that if we're thinking about biodiversity, then we're not necessarily talking about the utility it creates for people, and because biodiversity is a very difficult concept, in my opinion, we also need to be humble when dealing with nature." (Specialist/Counsellor, Government 02)

"Biodiversity as a term is certainly a bit challenging, and we do not really use it here in everyday life. So even to me, although I have an environmental management education and I knew what it was, as a concept, it was a bit tricky and how it was directly related to our business.” (Manager, Firm 15)

"But I'd say that also based on this private sector cooperation- [species] are not what interest people or businesses; instead, we need to be able to bring [biodiversity] closer to them. What does it mean from the actor's perspective? If I could or would be able to influence it, I'd take our communications more to the direction where we talk about ecosystem services. Perhaps it's on such a high level that we don't really know what people actually understand about biodiversity and, in a way, how we could make it easier for them to comprehend. I think these two different worlds [of business and biodiversity], they don't meet." (Specialist/Counsellor, Government 01) 
The model highlights that the continuous reflections that the change makers have on their constellations of concerns, especially the planetary grand challenge of biodiversity loss, but also the effectiveness of their change efforts, help them to calibrate their courses of actions (Archer, 2007). Indeed, the equivocality (Townsend et al., 2018) that characterizes the interstitial biodiversity protection issue field necessitates reflexivity that the change makers do also in their personal lives. In terms of time, we see that individuals entering the issue field can cycle through these set of actions in conversation with other actors over the course of a limited amount of time, such as a single training day. Reflection enables them to grapple to understand the issue, its connections to their organization, and the plurality of meanings that exist in the field. The ongoing internal and external conversations on the issue and their change efforts also help to make key change makers' actions increasingly rehearsed and effective over time. Yet, even actors who have worked and stayed in the field over an extended period of time continue to cycle through, and iterate back and forth between, the actions as new actors and interpretations enter or are introduced to the field:

"Hard to say how [the positive way of interacting with firms] has been built. Much of our activity has changed over the years, and the importance has grown so much. Of course, I believe, or at least, it's what I've heard, that the work becomes much easier when this topic is becoming more and more important and strategic for businesses. It's now easy to take the topic to [managers of] companies when they need all these perspectives." (Manager, Nonprofit 06)

"Now this [work] is going really well, it works, and we have found - but the first years were really difficult, to even find the [company] practices.... grasping the content, what should be told and when, and what to do, et cetera. [Now], we have learned what needs to be done, and how you can inspire and help businesses. And, we immediately understood that if there is no top management support, then the employees have no chance - this requires enthusiastic employees. If the persons 
who take a training are enthusiastic, then it starts to proceed ... These types of lessons are put into practice all the time. Many good things have happened, but this requires all of those elements." (Specialist/Counsellor, Government 03)

The above quotes indicate the nested structure of the three sequential actions, which are continuously calibrated via silent conversations. Each of these steps-filtering, modeling and translating — performed by the change makers reduces equivocality for other actors, and each action can best take place when the individual in question has done their own reflecting. In other words, when an individual reaches an inflection point in his/her own reflection process, it can trigger the same process at a higher level — a seminar or training group, firm managers or a group of other actors that occupy the issue field. Moreover, over time, these actions become increasingly effective as the change makers become progressively skilled at filtering, modeling and translating the biodiversity issue to others. The biodiversity protection work hence "becomes much easier" as the targets of the action in the field more easily sense the urgency, but not hopelessness, of the situation, observe the connections, and find a common language with the key change makers.

Overall, the cycle can be viewed as a process of reflection and reckoning that takes place repeatedly and at varying paces, stages and levels (also Whiteman \& Cooper, 2000; Muñoz \& Cohen, 2017) among actors in the field. Yet, even when multiple change makers simultaneously go through similar or joint silent conversations and increasingly skillfully cycle through these three actions, in the issue field as a whole, there are no objective answers on biodiversity and its preservation, and no single way to settle the field; rather, collectively equivocality persists.

\section{DISCUSSION}

In this study, we explored the silent conversations of change makers as they individually and jointly reflected on biodiversity with the aim of seeking to help other actors of 
the field to make sense of the issue and to engage in its protection. We drew from Archer (2007) while examining how the silent conversations taking place within the field influence the webs of action by individual change makers. The mental exercises highlight not only the existence of considerable equivocality around the issue of biodiversity but also the shared experiences and existential concerns that occupy the change makers at work, as well as in their private lives (Schabram \& Maitlis, 2017; Sonenshein et al., 2014). Our analysis shows that the reflections of change makers lead to three actions: filtering, modeling, and translating. These actions accentuate the iterative and nested processes of sensemaking and sensegiving that take place at multiple levels. Hence, our study corroborates Suddaby et al.'s (2017) assertion that the roles of human agency and reflexivity need to be recognized and explored in institutional (change) processes.

At an individual level, one's relationship with nature contextualizes the varying and often existential ways in which the individual change makers entering and operating in the interstitial issue field engage in biodiversity protection. The silent conversations about nature that many change makers have within their own heads or with others draw a rather pessimistic picture of the biodiversity crisis. They indicate anxieties and an anticipation of the inevitable losses that humans will soon face. The missing connection between a likely future crisis and the normality of daily life creates a sense of powerlessness and agony that many change makers experience: the crisis resides within the scale of global economic activities and mega trends, whereas the actors operate at the individual, firm, (supply) network and field levels. Their nuanced actions aimed at overcoming this sense of powerlessness suggest that many change makers are attuned to the role that emotions can play in actions toward sustainability (Archer, 2007; Schabram \& Maitlis, 2017; Russell et al., 2017). 
Paradoxically, the grim reality of loss of biodiversity motivates many change makers because it gives added meaning to their work - it is at the same time personally important and associated with an existential challenge of society at large. Here, the obscure yet unfolding danger mobilizes change and keeps the change makers going. At a higher level of analysis (i.e., group, organization, and field), the change makers' external conversations allow them to negotiate about the definitions and meanings of biodiversity, including new interpretations, such as ecosystem services and natural capital, which are introduced to the issue field. Hence, not only does biodiversity protection in this interstitial field carry its traditional meaning of species and habitat protection, but one can also speak of it using other languages that potentially make it easier for ordinary people and managers to understand the issue and act upon it.

Importantly, our findings suggest that in the interstitial biodiversity protection field, individuals add equivocality by seeking closure of their own interpretation of the significance, relevance and meaning of biodiversity (loss). This contradicts the findings of extant studies, which have treated issue fields as spaces where equivocality gets resolved. What our inductive insights reveal is that resolution at the individual level increases rather than decreases collective equivocality within the field. The temporal suspension of equivocality in this filtering-modeling-translating process allows change makers and other institutional actors to reach a negotiated temporal settlement about the relevant issues and necessary actions. Nevertheless, the temporal suspension these individuals orchestrate for select audiences does not yield permanent solutions for the field overall. Different individuals and organizations will always interpret biodiversity in their own way and from the perspective of their own context, and biodiversity protection as an issue field will continue to evolve. 
Our analysis shows how silent internal and external conversations help individual change makers manage the uncertainty and equivocality associated with creating engagement in biodiversity protection. The reflections and actions by change makers help push biodiversity to the forefront as a critical concern that is interlinked with climate change within the overall sustainability and CSR agenda. Hence, our study takes an incremental step in investigating how silent conversations and initial actions influence collective action and interaction, which, indeed, need to be a part of the overall solutions to (planetary boundary) grand challenges (Ferraro et al., 2015) or other wicked problems (Churchmann, 1967; Waddock, Meszoely, Waddell, \& Dentoni, 2015). We argue that reflexivity is essential in understanding the germination and propagation of ideas that create a profound institutional change in issue fields.

In sum, our inductive investigation took place at a time when managers of firms and other organizations in Finland were seeking to launch, implement, and mainstream increasingly ambitious biodiversity-oriented initiatives. It is still an evolving and emergent issue for many organizations and the public, and the issue field itself is in flux with additional actors and ideas entering the field. While our interviewees pointed out with confidence that biodiversity will, in the future, be considered as important as climate change in the sustainability agendas of firms, coordinated action and meaningful change related to biodiversity protection are still in the making. Moreover, there is a need for the public to recognize biodiversity loss as a grand challenge. Better understanding of these institutional change processes and how internal and external conversations induce collective action will further advance the theory of regenerative organizing and, more broadly, regenerative social systems.

\section{IMPLICATIONS FOR RESEARCH, PRACTICE, AND POLICY}


Our study makes several contributions to and has implications for the further study of institutional fields, human agency, and reflexivity. With regard to research on institutional fields, our study capitalizes on the opportunity to analyze the necessary next steps after the initiation of change by government but also various other actors within the interstitial issue field. This is valuable because "the diffusion of institutional change depends not on the original actions of the agent for change, but on their enrollment in a wider network, work that might be carried out by other actors building on the possibilities now indicated by the original actor" (Mutch, 2007, p. 1137). Specifically, by advancing research on interstitial issue fields (e.g., Zietsma et al., 2017), we show how individual change makers manage equivocality in the interstitial field of biodiversity protection through reflexive processes. Through the processes of filtering, modeling and translating, change makers try to grapple with the issue and create ways to engage others in the work for biodiversity. The reflexive processes initiated by change makers do not resolve equivocality in the interstitial field, as indicated in the existing literature. Rather, individuals' attempts to reach closure of their own interpretations increase collective equivocality, even when their actions become progressively more sophisticated. By focusing on change makersspecifically, their silent internal and external conversations and attempts to engage others through action - this study shows how regeneration in this context represents an existential quest for them, and paves the way for further studies on regeneration at the individual level.

In the future, we need studies that shift the analytic perspective increasingly from key change makers to the targets of action, to understand how they reflect on the issue and whether they experience less or more equivocality following the actions taken by the key change makers. For example, future studies could investigate in more detail how individuals representing different organizations and fields perceive the challenge and meanings related to biodiversity loss, or 
whether younger generations, who have been exposed to information on grand challenges early on, are more inclined to be involved in regeneration. Furthermore, the reflections of individuals are clearly linked with their strong emotions and values (Archer, 2007). This deserves more research, as previous studies point to the important yet varied ways in which emotions and values can play out in actions and work that focus on sustainability concerns and other callings (Schabram \& Maitlis, 2017; Russell et al., 2017; Ritvala \& Salmi, 2010). In particular, we need to know how managers of businesses react to the change makers' emotion-laden appeals for biodiversity protection and how they respond to such messages and proceed to push for the needed changes in business practice and the broader institutional field.

Our study also has managerial and policy implications related to company actions that tackle biodiversity loss and other sustainability problems. In this regard, the key takeaways of our study are the promotion of regenerative organizing by change makers and their potential ways of influencing others. In particular, we suggest that the actions of filtering, modeling, and translating form a base for driving concrete actions and creating engagement for biodiversity protection. In trying to understand and address their impacts on biodiversity, company managers can consider the examples reported in our study and use them as benchmarks.

With regard to policy implications, our data and findings clearly show that the issue of biodiversity loss has been neglected and overshadowed by other sustainability problems, such as climate change, in the international political arena. The fact that there are currently only 21 national or regional initiatives within the Business and Biodiversity network of the CBD suggests that so far, few countries across the globe have created ambitious targets in relation to biodiversity or are actively driving change through business action to slow down or stop biodiversity loss. Considering the magnitude of the issue, it is evident that the aggregate change that will be achieved 
through organizational and individual action within these countries is far from enough. To more effectively counterbalance global mega trends, such as population growth and the increase in ecological footprints, a greater number of countries and a variety of actors would need to be a part of international biodiversity protection efforts. This call to action is particularly timely, as the current CBD Strategic Plan and Aichi targets only extend until 2020, and a new post-2020 biodiversity framework is in preparation (CBD, 2019). Indeed, our results suggest that policy makers would be wise to not only carefully evaluate and consider the main drivers of biodiversity loss in their countries but also to support efforts for raising awareness and driving engagement among private sector actors, in particular. While the path to this is not linear and is rife with equivocality, the three actions of filtering, modeling, and translating can provide a starting point for creating engagement and change in other contexts, as well.

\section{CONCLUSION}

In this study, we focused on individual change makers' reflections and attempts to manage the uncertainty and equivocality involved in tackling the grand challenge of biodiversity loss. We provided insights into how silent conversations influenced their courses of action, especially in terms of seeking to engage others in biodiversity protection. Our findings suggest that as individuals, we are perplexed by planetary boundary grand challenges, and that individually and collectively, we are a part of the unfolding narratives. We are the source of the problems and, hopefully, also the solutions. This raises the question of whether and how human agency can transcend and save us from the collapse of civilization. In this study, we take an incremental step tiptoeing into this re-enchanted world (Suddaby et al., 2017; also see Hoffman \& Sandelands, 2005; Ivey, 2018), which comprises inner and outer—both natural and social—elements. We see each change maker embarking on his or her own journey through this multi-dimensional world 
(Archer, 2007; also Campbell, 2014). The adventures of the change makers-as well as ours, as researchers - are guided by reflexivity. Throughout these journeys, the natural world continues to impress and surprise us, reminding us of our ecological embeddedness (Archer, 2000, 2007; Whiteman \& Cooper, 2000) and requiring us to assimilate and manage the equivocality added by it. The abstract grand challenge of biodiversity loss becomes inherently human, and its protection should be a quest for us all.

\section{Acknowledgments}

We are sincerely grateful for the detailed feedback and guidance provided to us during the review process and for the support and comments received from our colleagues at the Academy of Management Annual Meeting 2018 All-Academy Symposium.

\section{Funding}

The first author thankfully acknowledges a research grant from Foundation for Economic Education in Finland (Liikesivistysrahasto). 


\section{REFERENCES}

Albrecht, G., Sartore, G. M., Connor, L., Higginbotham, N., Freeman, S., Kelly, B., ... \& Pollard, G. (2007). Solastalgia: the distress caused by environmental change. Australasian Psychiatry, 15(sup1), S95-S98.

Archer, M. S. (2000). Being human: The problem of agency. Cambridge: University Press.

Archer, M. S. (2007). Making our way through the world: Human reflexivity and social mobility. Cambridge: University Press.

Bansal, B., Smith, W. K., \& Vaara, E. (2018). New ways of seeing through qualitative research, Academy of Management Journal, 61(4), 1189-1195

CAFF. (2015). Actions for arctic biodiversity, 2013-2021: Implementing the recommendations of the Arctic Biodiversity Assessment. Conservation of Arctic Flora and Fauna, Akureyri, Iceland. ISBN: 978-9935-431-41-7

Campbell, J. (2014). The hero's journey: Joseph Campbell on his life and work. Ed. P. Cousineau. New World Library.

Churchman, C. W. (1967). Guest editorial: Wicked problems. Management Science, 14(4), B141B142.

Cohen, B., \& Muñoz, P. (2015). Toward a theory of purpose-driven urban entrepreneurship. Organization \& Environment, 28(3), 264-285.

Convention on Biological Diversity (CBD). (2005). Handbook of the Convention of Biological Diversity: Including Its Cartagena protocol on biosafety, 3rd edition, Montreal: Secretariat of the Convention on Biological Diversity. Retrieved from: https://www.cbd.int/doc/handbook/cbd-hball-en.pdf

CBD (Convention on Biological Diversity). (2014). Global biodiversity outlook 4. Montréal: Secretariat of the Convention on Biological Diversity, 155 pages.

CBD (Convention on Biological Diversity). (2018). The Global Partnership for Business and Biodiversity. Montréal: Secretariat of the Convention on Biological Diversity. Retrieved from: https://www.cbd.int/business/gp.shtml

CBD (Convention on Biological Diversity). (2019). Preparations for the post-202 biodiversity framework. Retrieved on January 28, 2019 from: https://www.cbd.int/post2020/

Crist, E., Mora, C., \& Engelman, R. (2017). The interaction of human population, food production, and biodiversity protection. Science, 356(6335), 260-264.

Daft, R. L., Lengel, R. H., \& Trevino, L. K. (1987). Message equivocality, media selection, and manager performance: Implications for information systems. MIS Quarterly, 11(3), 355-366. 
Daft, R. L., \& Macintosh, N. B. (1981). A tentative exploration into the amount and equivocality of information processing in organizational work units. Administrative Science Quarterly, 26, 207-224.

EU. (2011). EU Biodiversity Strategy. Retrieved from: http://ec.europa.eu/environment/nature/biodiversity/strategy/index_en.htm. EU.

EU. (2015). Mid-term review of the EU biodiversity strategy to 2020. EU assessment of progress towards the targets and actions. Retrieved from: http://ec.europa.eu/environment/nature/biodiversity/comm2006/pdf/mid_term_review_summary. pdf. EU.

Ferraro, F., Etzion, D., \& Gehman, J. (2015). Tackling grand challenges pragmatically: Robust action revisited. Organization Studies, 36(3), 363-390.

FIBS. (2015). Added value from nature to sustainable business. Biodiversity and ecosystem services as a foundation for environmental strategy. Helsinki: Finnish Business and Society. Retrieved from: www.fibsry.fi/fi/english/themes/business-biodiversity.

Fligstein, N. (2013). Understanding stability and change in fields. Research in Organizational Behavior, 33, 39-51.

Furnari, S. (2014). Interstitial spaces: Microinteraction settings and the genesis of new practices between institutional fields. Academy of Management Review, 39(4), 439-462.

George, G., Howard-Grenville, J., Joshi, A., \& Tihanyi, L. (2016). Understanding and tackling societal grand challenges through management research. Academy of Management Journal, 59(6), 1880-1895.

Granqvist, N., \& Laurila, J. (2011). Rage against self-replicating machines: Framing science and fiction in the US nanotechnology field. Organization Studies, 32(2), 253-280.

Greenwood, R., Suddaby, R., \& Hinings, C. R. (2002). Theorizing change: The role of professional associations in the transformation of institutionalized fields. Academy of Management Journal, $45(1), 58-80$.

Grigg, A. (2007). Biodiversity and the extractive industry: Innovative practices and remaining challenges. Greener Management International, 52(Spring), 63-76.

Grodal, S., \& O’Mahony, S. (2017). How does a grand challenge become displaced? Explaining the duality of field mobilization. Academy of Management Journal, 60(5), 1801-1827.

Hahn, T., \& Pinkse, J. (2014). Private environmental governance through cross-sector partnerships: Tensions between competition and effectiveness. Organization \& Environment, $27(2), 140-160$. 
Hanski, I. (2016). Tutkimusmatkoja saarille. Luonnon monimuotoisuutta kartoittamassa. Tallinn: Gaudeamus.

Hoffman, A.J. (1999). Institutional evolution and change: Environmentalism and the U.S. chemical industry. Academy of Management Journal, 42(4), 351-371.

Hoffman, A. J., \& Sandelands, L. E. (2005). Getting right with nature: Anthropocentrism, ecocentrism, and theocentrism. Organization \& Environment, 18(2), 141-162.

IPCC. (2018). Global Warming of $1.5^{\circ} \mathrm{C}$ : An IPCC special report on the impacts of global warming of $1.5^{\circ} \mathrm{C}$ above pre-industrial levels and related global greenhouse gas emission pathways, in the context of strengthening the global response to the threat of climate change, sustainable development, and efforts to eradicate poverty. Intergovernmental Panel on Climate Change (IPCC). Retrieved from: http://www.ipcc.ch/report/sr15/

Ivey, B. (2018). Rebuilding an enlightened world: Folklorizing America. Indiana University Press.

Kolbert, E. (2014). The sixth extinction: An unnatural history. A\&C Black.

Kolbert, E. (2018, October 15). How to write about a vanishing world. The New Yorker. Retrieved from: $\quad$ https://www.newyorker.com/magazine/2018/10/15/how-to-write-about-a-vanishingworld? mbid=nl_Daily\%20101118\&CNDID $=21574055 \& u t m \_$source $=$Silverpop \&utm_medium $=$ email\&utm_campaign=Daily\%20101118\&utm_content $=\&$ spMailingID $=14416069 \&$ spUserID= MTMzMTc5NzgOMDY1SO\&spJobID=1500889217\&spReportId=MTUwMDg4OTIxNwS2

Le Ber, M. J., \& Branzei, O. (2010). Value frame fusion in cross sector interactions. Journal of Business Ethics, 94(1), 163-195.

Maguire, S., Hardy, C., \& Lawrence, T. B. 2004. Institutional entrepreneurship in emerging fields: HIV/AIDS treatment advocacy in Canada. Academy of Management Journal, 47: 657-679.

Ministry of the Environment (2018). International Cooperation on Nature Conservation. Accessed on September 10, 2018 at: http://www.ym.fi/enUS/Nature/Biodiversity/International_cooperation.

Ministry of the Environment. (2014). Fifth national report to the Convention on Biological Diversity - Finland. Helsinki: Ministry of the Environment.

Ministry of the Environment. (2012). Saving Nature for People: National Action Plan for the Conservation and Sustainable Use of Biodiversity in Finland 2013-2020. Helsinki: Ministry of the Environment.

Muñoz, P. \& Cohen, B. (2017). Towards a social-ecological understanding of sustainable venturing. Journal of Business Venturing Insights, 7, 1-8. 
Mutch, A. (2007). Reflexivity and the institutional entrepreneur: A historical exploration. Organization studies, 28(7), 1123-1140.

O'Mahony, S., \& Bechky, B. A. (2008). Boundary organizations: Enabling collaboration among unexpected allies. Administrative Science Quarterly, 53(3), 422-459.

Patton, M. (1990). Qualitative evaluation and research methods. London: Sage.

Purdy, J. M., \& Gray, B. (2009). Conflicting logics, mechanisms of diffusion, and multilevel dynamics in emerging institutional fields. Academy of Management Journal, 52(2), 355-380.

Quarshie, A.M., \& Leuschner, R. (2018). Cross-sector social interactions and systemic change in disaster response: A qualitative study. Journal of Business Ethics, 150(2), 357-384.

Ripple, W. J., Wolf, C., Newsome, T. M., Galetti, M., Alamgir, M., Crist, E., .. \& 15,364 scientist signatories from 184 countries. (2017). World scientists' warning to humanity: A second notice. BioScience, 67(12), 1026-1028.

Ritvala, T., \& Salmi, A. (2010). Value-based network mobilization: A case study of modern environmental networkers. Industrial Marketing Management, 39(6), 898-907.

Russell, S. V., Young, C. W., Unsworth, K. L., \& Robinson, C. (2017). Bringing habits and emotions into food waste behaviour. Resources, Conservation and Recycling, 125, 107-114.

Schabram, K., \& Maitlis, S. (2017). Negotiating the challenges of a calling: Emotion and enacted sensemaking in animal shelter work. Academy of Management Journal, 60(2), 584-609.

Sonenshein, S., DeCelles, K.A., \& Dutton, J.E. (2014). It's not easy being green: the role of self-evaluations in explaining support of environmental issues. Academy of Management Journal, 57(1), 7-37.

Steffen, W., Richardson, K., Rockström, J., Cornell, S.E., Fetzer, I., Bennet, E.M., Biggs, R., Carpenter, S.R., De Vries, W., De Wit, C.A., et al.. (2015). Planetary boundaries: Guiding human development on a changing planet. Science 347 (6223): 1259855-1 - 1259855-10. Doi: 10.1126/science. 1259855

Stockholm Resilience Centre. (2018). The Nine Planetary Boundaries. Accessed on September 15, 2018 at: http://www.stockholmresilience.org/research/planetary-boundaries/planetaryboundaries/about-the-research/the-nine-planetary-boundaries.html.

Suddaby, R., Viale, T., \& Gendron, Y. (2016). Reflexivity: The role of embedded social position and entrepreneurial social skill in processes of field level change. Research in Organizational Behavior, 36, 225-245.

Suddaby, R., Ganzin, M., \& Minkus, A. (2017). Craft, magic and the re-enchantment of the world. European Management Journal, 35(3), 285-296. 
Townsend, D.M., Hunt, R.A., McMullen, J.S., \& Sarasvathy, S. (2018). Uncertainty, knowledge problems and entrepreneurial action. Academy of Management Annals, 12(2), 659-687.

United Nations. (2015). Transforming our world: The 2030 agenda for sustainable development. New York: United Nations.

Van Wijk, J., Stam, W., Elfring, T., Zietsma, C., \& Den Hond, F. (2013). Activists and incumbents structuring change: The interplay of agency, culture, and networks in field evolution. Academy of Management Journal, 56(2), 358-386.

Waddock, S., Meszoely, G. M., Waddell, S., \& Dentoni, D. (2015). The complexity of wicked problems in large scale change. Journal of Organizational Change Management, 28(6), 993-1012.

Weick, K. E. (1979). The social psychology of organizing. Columbus, OH: McGraw-Hill Humanities.

Whiteman, G., \& Cooper, W. H. (2000). Ecological embeddedness. Academy of Management Journal, 43(6), 1265-1282.

Whiteman, G., Walker, B., \& Perego, P. (2013). Planetary boundaries: Ecological foundations for corporate sustainability. Journal of Management Studies, 50(2), 307-336.

WWF. (2016). Living planet report 2016: Risk and resilience in a new era. World Wide Fund for Nature.

Zack, M. H. (2001). If managing knowledge is the solution, then what's the problem?. In Knowledge management and business model innovation (pp. 16-36). IGI Global.

Zietsma, C., Groenewegen, P., Logue, D. M., \& Hinings, C. R. (2017). Field or fields? Building the scaffolding for cumulation of research on institutional fields. Academy of Management Annals, $11(1), 391-450$.

Zietsma, C., \& Lawrence, T. B. (2010). Institutional work in the transformation of an organizational field: The interplay of boundary work and practice work. Administrative Science Quarterly, 55(2), 189-221. 


\section{Figure 1: Key Events in Biodiversity Protection Issue Field}

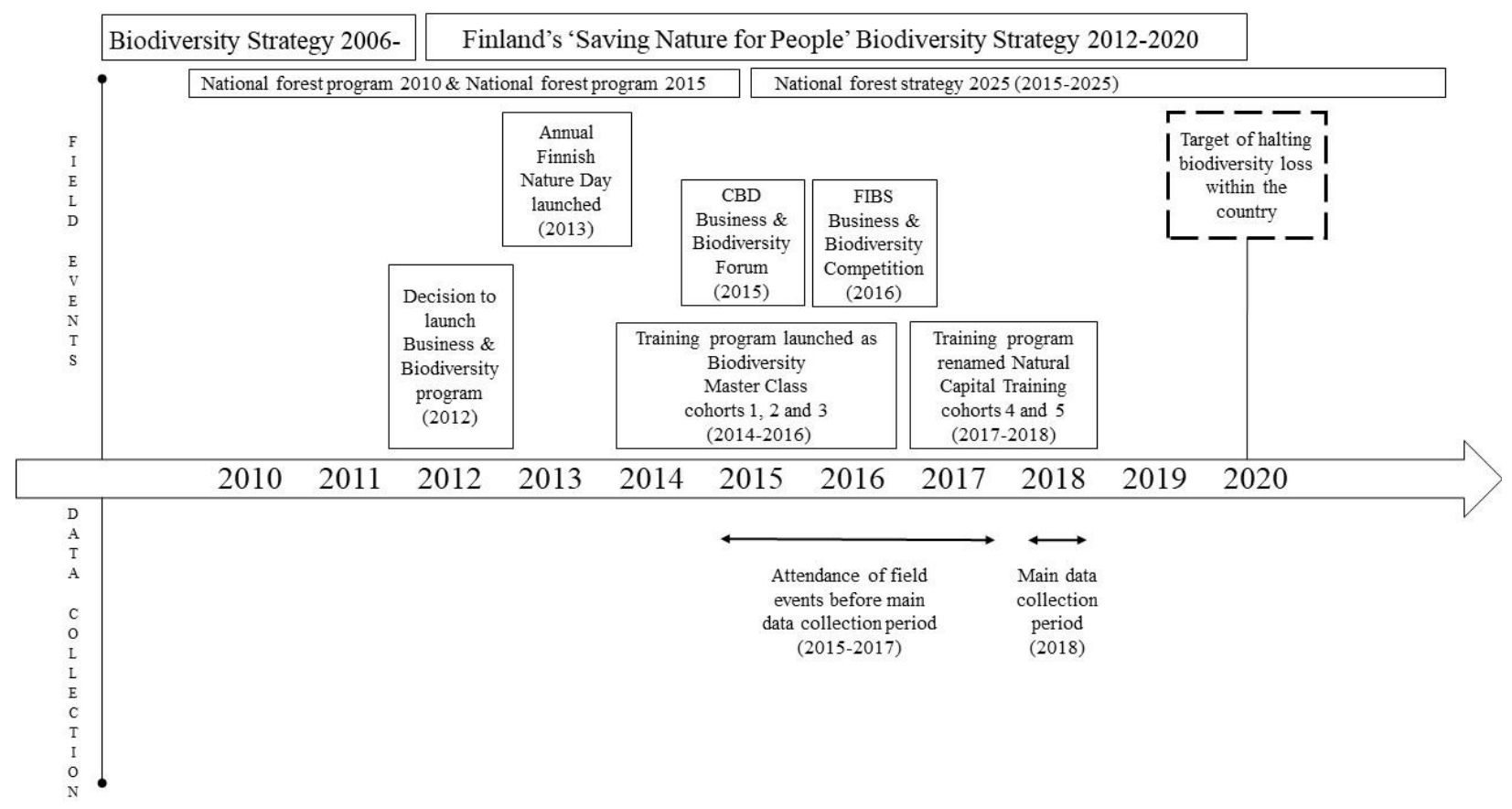


Figure 2: Recursive Process

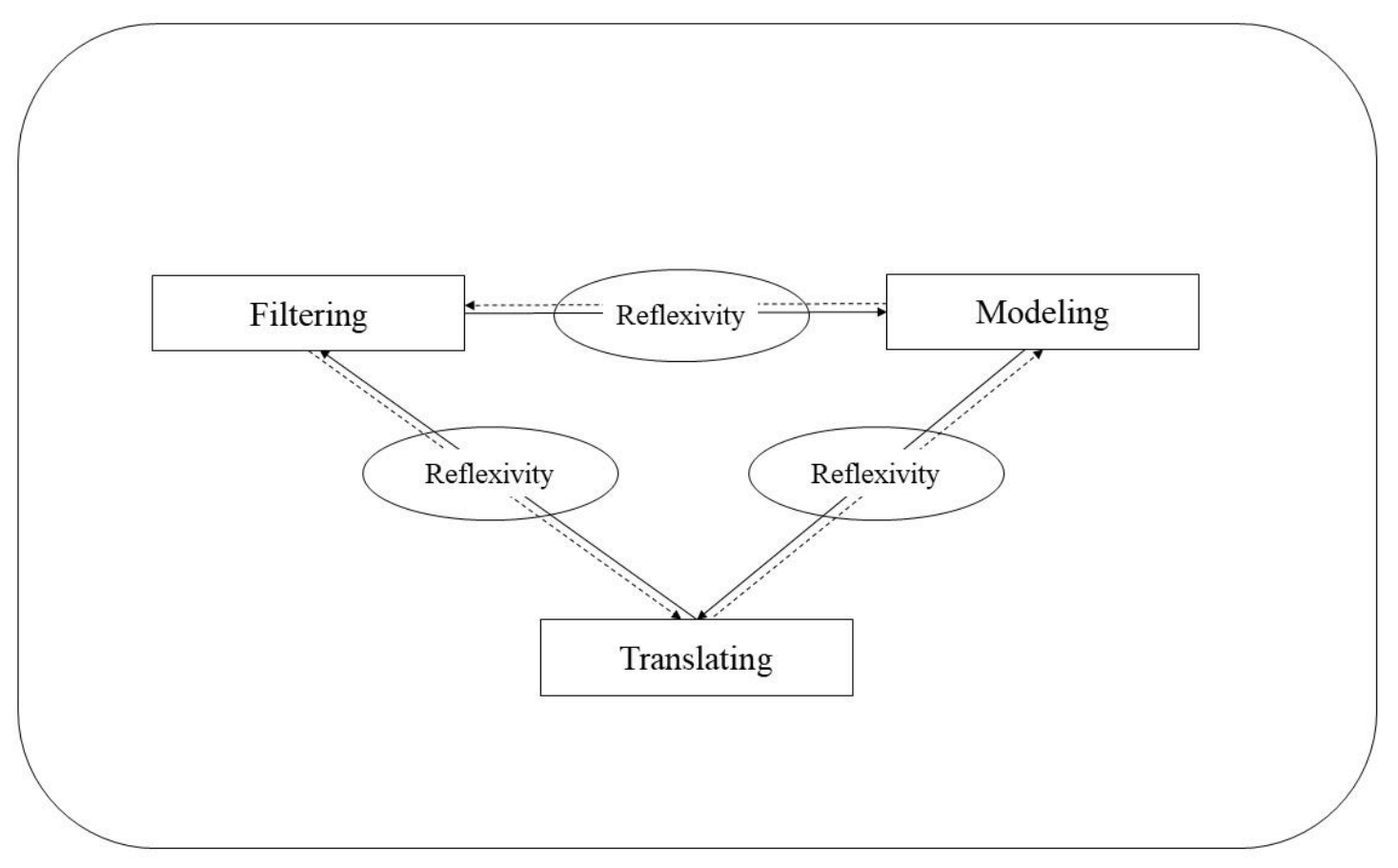


Table 1: Interviewed Organizations and Informants

\begin{tabular}{|c|c|c|c|}
\hline $\begin{array}{c}\text { Organization } \\
\text { Code }\end{array}$ & Sector & Informant Position & $\begin{array}{c}\text { Interview } \\
\text { Length } \\
\text { (Minutes) }\end{array}$ \\
\hline Government 01 & Government & Specialist/Counsellor & 80 \\
\hline Government 02 & Government & Specialist/Counsellor & 80 \\
\hline Government 03 & Government & Specialist/Counsellor & 135 \\
\hline Nonprofit 04 & Nonprofit & Director/Executive & 115 \\
\hline Nonprofit 05 & Nonprofit & Manager & 50 \\
\hline Nonprofit 06 & Nonprofit & Manager & 120 \\
\hline Nonprofit 07 & Nonprofit & Manager & 90 \\
\hline Nonprofit 08 & Nonprofit & Specialist & 70 \\
\hline Nonprofit 09 & Nonprofit & Director/Executive & 80 \\
\hline Nonprofit 10 & Nonprofit & Director/Executive & 60 \\
\hline Firm 11 & Private sector / food & Manager & 75 \\
\hline Firm 12 & Private sector / food & Director/Executive & 60 \\
\hline Firm 13 & Private sector / food & Manager & 75 \\
\hline Firm 14 & Private sector / food & Director/Executive & 60 \\
\hline Firm 15 & Private sector / consumer goods & 60 \\
\hline Firm 16 & Private sector / consumer goods & Director/Executive & 75 \\
\hline Firm 17 & Private sector / consumer goods and & services & 60 \\
\hline Firm 18 & Private sector / consumer services & Manager & 50 \\
\hline Firm 19 & Private sector / services & Director/Executive & 50 \\
\hline Firm 20 & Private sector / services & Manager & 60 \\
\hline Firm 21 & Private sector / forestry & Manager & 60 \\
\hline Firm 22 & Private sector / forestry & Manager & 70 \\
\hline Firm 23 & Private sector / construction and \\
& maintenance & Director/Executive & 75 \\
\hline Firm 24 & Private sector / construction and & maintenance & 55 \\
\hline Firm 25 & Private sector / construction and \\
maintenance & Director/Executive & 65 \\
\hline Firm 26 & Private sector / heavy industry & Director/Executive & 55 \\
\hline Firm 27 & Private sector / heavy industry & & \\
\hline & & & 55 \\
\hline
\end{tabular}


Table 2: Summary of Archival Materials

\begin{tabular}{|c|c|c|}
\hline Data Type & $\begin{array}{l}\text { Number of } \\
\text { Documents }\end{array}$ & Use in Research and Analysis \\
\hline $\begin{array}{l}\text { FIBS } \\
\text { biodiversity } \\
\text { training and } \\
\text { seminar } \\
\text { materials }\end{array}$ & 34 & $\begin{array}{l}\text { During data collection, these materials helped us determine the actors involved in activities in this field and make initial } \\
\text { sampling decisions. During data analysis, the materials helped us better comprehend the biodiversity issue, its causes and } \\
\text { interlinkages with other sustainability problems, various ways of defining and interpreting it, possible company approaches } \\
\text { to it, and how various industries are connected with it. Furthermore, the materials helped us understand how firms are trained } \\
\text { on it, the terms and concepts that are emphasized, and the types of responses and solutions that exist. }\end{array}$ \\
\hline $\begin{array}{l}\text { FIBS } \\
\text { biodiversity } \\
\text { publications } \\
\text { (e.g., training } \\
\text { reports) }\end{array}$ & 5 & $\begin{array}{l}\text { These materials aided us in the research design, initial sampling decisions, and the interview preparation, as we could see } \\
\text { which industries and organizations participated in trainings (as participants and trainers). Through these materials, we could } \\
\text { better understand the evolution of the training program (e.g., terms and concepts used) and the variations in } \\
\text { company/organizational interpretations of the issue. The materials also provided rich details about company/organizational } \\
\text { responses to the issue, other actions to induce change, and the results of these activities. }\end{array}$ \\
\hline $\begin{array}{l}\text { FIBS website } \\
\text { materials }\end{array}$ & 10 & $\begin{array}{l}\text { These online materials allowed us to identify the types of activities (biodiversity-related seminars and trainings) that were } \\
\text { offered and the firms and organizations that participated in events. These materials therefore aided in the sampling of initial } \\
\text { informants and in preparing for the interviews. They also helped us to understand the evolution of the training program (e.g., } \\
\text { terms and concepts used), the field actions to induce change, and the results of these activities. }\end{array}$ \\
\hline $\begin{array}{l}\text { Company CSR, } \\
\text { sustainability } \\
\text { and annual } \\
\text { reports }\end{array}$ & 19 & $\begin{array}{l}\text { These materials helped us prepare for the interviews by providing basic information about the firm and its activities. They } \\
\text { also helped us determine the weight that firms give to the biodiversity issue compared with other sustainability concerns. } \\
\text { During analysis, we could better understand how biodiversity is integrated and framed in company annual/sustainability/CSR } \\
\text { reports and the terms and concepts that are used in discussing the issue. We were also able to learn about industry-specific } \\
\text { impacts, interdependencies and responses, company actions to address the issue, and the results of these activities. }\end{array}$ \\
\hline $\begin{array}{l}\text { Company } \\
\text { websites }\end{array}$ & 20 & $\begin{array}{l}\text { These materials helped us prepare for the interviews, such as by providing basic information about the firm and the } \\
\text { informant. They also provided us details about industry-specific impacts and interdependencies, company actions, and the } \\
\text { results of activities. }\end{array}$ \\
\hline $\begin{array}{l}\text { Government } \\
\text { biodiversity } \\
\text { strategies, plans, } \\
\text { and reports }\end{array}$ & 11 & $\begin{array}{l}\text { These materials helped us in sampling decisions and in preparing for the interviews. They also advanced our understanding } \\
\text { of the Finnish government's commitments related to biodiversity, strategies and action plans made, activities and actions } \\
\text { concerning firms and the private sector, the progress made to date, opportunities and challenges/constraints in the social } \\
\text { system, and the broader institutional, environmental, social, and economic contexts of our study. }\end{array}$ \\
\hline $\begin{array}{l}\text { Government } \\
\text { websites }\end{array}$ & 4 & $\begin{array}{l}\text { These materials helped us prepare for the interviews, such as by providing basic information about the organization and the } \\
\text { informant. They also helped us understand the broader context of our study. }\end{array}$ \\
\hline $\begin{array}{l}\text { Nonprofit } \\
\text { organization } \\
\text { reports }\end{array}$ & 3 & $\begin{array}{l}\text { These materials helped us in sampling decisions and in preparing for the interviews. They also aided our understanding of } \\
\text { the severity of the biodiversity issue, industry- and ecosystem-specific issues, opportunities and challenges/constraints in the } \\
\text { system, and the broader institutional, environmental, social, and economic contexts of our study. }\end{array}$ \\
\hline $\begin{array}{l}\text { Nonprofit } \\
\text { organization } \\
\text { websites }\end{array}$ & 6 & $\begin{array}{l}\text { These materials helped us in sampling decisions and in preparing for the interviews. They also aided our understanding of } \\
\text { the severity of the biodiversity issue, industry- and ecosystem-specific issues, opportunities and challenges/constraints in the } \\
\text { system, and the broader institutional, environmental, social, and economic contexts of our study. }\end{array}$ \\
\hline Total & 112 & \\
\hline
\end{tabular}




\section{Table 3: Variation in Interpretations of Biodiversity}

\begin{tabular}{|c|c|}
\hline Interpretation & Illustrative Quote (Informant, Organization) \\
\hline $\begin{array}{l}\text { Biodiversity as an } \\
\text { unclear or } \\
\text { irrelevant issue }\end{array}$ & $\begin{array}{l}\text { "I'd say that we haven't looked at it very deeply, so we've been trying to think about whether it's } \\
\text { related to us, and we haven't found clear linkages to our activities. I have to say that we've } \\
\text { concentrated on the topics that are important to us. (Director/Executive, Firm 19) }\end{array}$ \\
\hline $\begin{array}{l}\text { Biodiversity as } \\
\text { leaving an intact } \\
\text { planet to future } \\
\text { generations }\end{array}$ & $\begin{array}{l}\text { "Simply put, the way I see it is that it's what we'll leave to the subsequent generations, how intact } \\
\text { the world or planet is that we leave to them. We all have a great responsibility over it, that all this } \\
\text { is transferred to them and preferably will increase. It's such a huge concept that I don't really } \\
\text { know." (Manager, Firm 18) }\end{array}$ \\
\hline $\begin{array}{l}\text { Biodiversity as } \\
\text { retaining the } \\
\text { earth's natural } \\
\text { functions }\end{array}$ & $\begin{array}{l}\text { "... but I think that [biodiversity] perhaps relates to the fact that the earth's natural functions } \\
\text { supporting human life can continue to work in the future. Maybe that is the bigger theme that it } \\
\text { relates to. Of course, this is a people-centered view, but maybe that is how I ultimately perceive } \\
\text { it. (Manager, Firm 20) }\end{array}$ \\
\hline $\begin{array}{l}\text { Biodiversity as a } \\
\text { topic related to } \\
\text { species and nature }\end{array}$ & $\begin{array}{l}\text { "People have often been talking about biodiversity as a question of species and natural habitats; } \\
\text { there's talk of endangered species_- that's the general message..." (Specialist/Counsellor, } \\
\text { Government 01) }\end{array}$ \\
\hline $\begin{array}{l}\text { Biodiversity as the } \\
\text { variation in species } \\
\text { and habitats/nature }\end{array}$ & $\begin{array}{l}\text { "In principle, it means genetic diversity, but when it comes to [company] planning processes, in } \\
\text { practice, it's quite difficult to get to the level of genes. But it means variation in nature, in } \\
\text { species, and taking these into consideration." (Manager, Firm 22) }\end{array}$ \\
\hline $\begin{array}{l}\text { Biodiversity as } \\
\text { something that can } \\
\text { be managed }\end{array}$ & $\begin{array}{l}\text { "What the concept of biodiversity or nature's diversity means to me is that in nature, you let all the } \\
\text { flowers bloom, so to speak, but at the same time, in the built environment, you have to take into } \\
\text { account that not everyone is as strong. Because of that, for historical or other reasons, humankind } \\
\text { can have effects on nature. You don't let everything sprawl, but you can take management actions, } \\
\text { which are mentioned in nature inventories, too. (Director/Executive, Firm 23) }\end{array}$ \\
\hline $\begin{array}{l}\text { Biodiversity as } \\
\text { nature } \\
\text { interdependencies }\end{array}$ & $\begin{array}{l}\text { "It's always as difficult, but in my view, biodiversity means that the company finds its own } \\
\text { nature interdependencies. That is the core idea for the company. Once these have been identified, } \\
\text { then, similar to other businesses, you can take the most critical or business-relevant matters } \\
\text { forward. Those are the ones with the largest impacts. Every company should go through a process } \\
\text { in which they think about it, for example, through ecosystem services. They think about or map } \\
\text { out their own connections, and if they do not recognize them, the connections will blow up in } \\
\text { their face later." (Manager, Nonprofit 07) }\end{array}$ \\
\hline $\begin{array}{l}\text { Biodiversity as } \\
\text { (the foundation of) } \\
\text { ecosystem services }\end{array}$ & $\begin{array}{l}\text { "We do tell [companies], of course, that biodiversity means many different things. In addition to } \\
\text { species, it means genetic diversity and other forms of diversity, and it is kind of like the entire } \\
\text { nature's balance that is built ... and it is presented using quite abstract terms. But, we go quite } \\
\text { soon to ecosystem services, which are so much more concrete and easier for companies to } \\
\text { understand. We talk about the fact that biodiversity is the foundation on which ecosystem } \\
\text { services are built; maybe this is the way how diversity is defined." (Manager, Nonprofit 06) }\end{array}$ \\
\hline $\begin{array}{l}\text { Biodiversity as } \\
\text { natural capital }\end{array}$ & $\begin{array}{l}\text { "When you start talking about [natural] capital, people who are responsible for financial things } \\
\text { become interested, like, 'capital, there are some euros behind the capital.' I'm sure that the term } \\
\text { is actually important for that kind of discussion, where you think about it in terms of value." } \\
\text { (Director/Executive, Firm 17) }\end{array}$ \\
\hline $\begin{array}{l}\text { Biodiversity as a } \\
\text { source of business } \\
\text { value }\end{array}$ & $\begin{array}{l}\text { "This is perhaps a little bit vague, but we feel it in the way that a) we are trying to exploit nature } \\
\text { as sustainably as possible, and that way, we support biodiversity. And, b), we also want to } \\
\text { compensate for the use of natural capital services, that is, the use of natural resources, in a way } \\
\text { that benefits the environment, in certain areas that are relevant to our business. So, in a way, we } \\
\text { link biodiversity to what creates value for [our] business. We do not take a holistic 'let's save the } \\
\text { world' perspective; it has to link to the business." (Manager, Firm 12) }\end{array}$ \\
\hline $\begin{array}{l}\text { Biodiversity as } \\
\text { greenwashing }\end{array}$ & $\begin{array}{l}\text { "I guess it's different for us compared with a shop or something else. I think that as we've been } \\
\text { involved in this [training] thing, in my own group, there was [company] and [company], and so } \\
\text { on, so it was incredibly interesting to listen to that stuff. I felt that it was ... but when [company] } \\
\text { was participating, I felt that it started to get really close to greenwashing." (Director/Executive, } \\
\text { Nonprofit 10) }\end{array}$ \\
\hline
\end{tabular}


Table 4: Actions

\begin{tabular}{|c|c|}
\hline $\begin{array}{l}\text { Category } \\
\text { Concept }\end{array}$ & Illustrative quote (Informant, Organization) \\
\hline $\begin{array}{l}\text { 1. Filtering } \\
\text { 1A. Removing negative } \\
\text { aspects or selecting } \\
\text { positive aspects }\end{array}$ & $\begin{array}{l}\text { 1A1. "... so I'm focusing on positive communication and so on. Companies will often want to focus on that kind of thing in their } \\
\text { communication because if communication gets too desperate and hopeless and negative, people will give up, and they don't have the } \\
\text { enthusiasm to do anything." (Manager, Nonprofit } 05 \text { ) } \\
\text { 1A2. "Instead, we only try to promote the issue in a positive way, which sometimes seems to be challenging, as sometimes, you would } \\
\text { like to criticize more business activities. But after all, it has been understood very well why you should act like this because we are a bit } \\
\text { like their friends, and it is much easier to get the matter forward in such a positive way." (Manager, Nonprofit 06) } \\
\text { 1B1." Then, there's the diversity discussion that's currently taking place through the theme of clearcutting. Environmental NGOs are } \\
\text { campaigning to end clearcutting in government-owned areas, and their arguments are maybe landscape, recreational use, and carbon- } \\
\text { related things. Diversity is there, too, but maybe not as strongly, since the clearcutting discussion isn't a silver bullet that would solve } \\
\text { our diversity challenges so that clearcutting would be ended in state-owned areas." (Manager, Firm } 21 \text { ) } \\
\text { 1B2. "[Forest owners] are the ones who take up the responsibility on carbon dioxide absorption and fulfill Finland's obligations, when } \\
\text { we should talk about how everyone pays Finland's obligations through their consumption. Again, we come to the starting point, that this } \\
\text { is a debate that even environmental organizations are not talking about. Last year, [the NGO] started to raise it a bit. And now I have } \\
\text { spoken with [NGO director] and others - because I think it is completely misleading that [they] only talk about some polar bears. It is } \\
\text { not about polar bears ... It would really require that everyone be involved. (Specialist/Counsellor, Government } 03 \text { ). }\end{array}$ \\
\hline $\begin{array}{l}\text { 2. Modeling } \\
\text { 2C. Using concrete } \\
\text { practices, solutions, and } \\
\text { tools as examples to } \\
\text { follow }\end{array}$ & $\begin{array}{l}\text { 2C1. "But then individual people at [a construction company] started doing some pilots and introducing good practices by simply } \\
\text { noticing on the field level that okay, they were digging some holes in the sand, and they noticed that there are sand martins on that sand } \\
\text { hill. Let's create a better spot over there, it's closer to water and so on, and that way, they were able to get the population to move, they } \\
\text { created an alternative spot for them. So, if there are people who have that knowledge about nature or thoughts about that, then good } \\
\text { solutions can also be created that way." (Specialist/Counsellor, Government 01) } \\
2 \mathrm{C} 2 \text {. "However, when you have that path to offer that is a concrete solution, it is easier ... Companies find it easier to get involved when } \\
\text { they know how it is handled, what the goal is, and that this is really good for us." (Director/Executive, Nonprofit 04) } \\
2 \mathrm{C} 3 \text { "... the guidelines are currently being updated, and we've promised to write about what after-care [in construction sites] means today } \\
\text { and what it has to enable in permits, and what has to be written about it so that we can support it. Through that, we're trying to change the, } \\
\text { maybe it's more about the attitude of the authorities that we want to change, but similarly, it's about the tools for companies so that they } \\
\text { can do concrete actions." (Director/Executive, Nonprofit 10) } \\
2 \mathrm{D} 1 . \text { "We told investors what [biodiversity] was all about, and I was there as one of the experts talking. There was an investor from } \\
\text { [bank], [individual name], who is an interesting person. He knows a lot about responsibility issues, even on a global scale. He was there } \\
\text { discussing from the banker's point of view what challenges there are in Europe and in the US." (Manager, Nonprofit } 07 \text { ) }\end{array}$ \\
\hline
\end{tabular}




\begin{tabular}{|c|c|}
\hline & $\begin{array}{l}\text { 2D2. "Of course it was wonderful to discuss about these things in a peer group and to hear about different companies' own experiences } \\
\text { of these things. Many companies are in very different situations. I personally first thought that, how could we involve biodiversity more } \\
\text { in this than we already have through the efficient use of resources? Since the examples were mostly from [construction] and things like } \\
\text { when you're building electricity lines and so on. How can you use the pastures, or when you take away nests from some birds, how can } \\
\text { you build others to replace them? So it felt very far-fetched for me to start thinking about things like these, since we're not doing } \\
\text { anything even close to that. But the more we went through it, [the more] we got insights. (Director/Executive, Firm 16) }\end{array}$ \\
\hline 3. Translating & \\
\hline $\begin{array}{l}\text { 3E. Changing words into } \\
\text { the language of the } \\
\text { audience }\end{array}$ & $\begin{array}{l}\text { 3E1. "It's a good question in the sense that ... the most essential thing is that the actors understand what this is about and that the actors } \\
\text { understand why they should do something." (Specialist/Counsellor, Government 02) } \\
\text { 3E2. "And then FIBS can speak the economic language, so it's acting as an interface and as an interpreter between two different } \\
\text { cultures, so that has been great." (Specialist/Counsellor, Government 01) }\end{array}$ \\
\hline $\begin{array}{l}\text { 3F. Selecting terms or } \\
\text { vocabularies that are } \\
\text { known or understood by } \\
\text { the audience }\end{array}$ & $\begin{array}{l}\text { 3F1. "[Natural capital] is not just about biodiversity, but it's about approaching environmental issues more broadly, but their approach, } \\
\text { however, was quite closely aligned with biodiversity. So, we translated the issue so that if you do not consider these things in your } \\
\text { business, then it will be a problem for you, and you'll miss things in decision making if you do not understand biodiversity at all. } \\
\text { Especially now, it's easier to promote biodiversity than it was four years ago, now that it's known that resources are scarce." (Manager, } \\
\text { Nonprofit 06) }\end{array}$ \\
\hline $\begin{array}{l}\text { 3G. Selecting related } \\
\text { issues or examples } \\
\text { understood by the } \\
\text { audience }\end{array}$ & $\begin{array}{l}\text { 3F2. "I speak from the perspective of other people now, an average portfolio manager's perspective. I would say that the term } \\
\text { [biodiversity] is not used in everyday life. I guess that biodiversity, as a word, is familiar to responsible investment experts and the } \\
\text { company's responsibility experts. You could also say that an investor's definition of ESG factors is that it's what is essential to the } \\
\text { return-let's focus on those [things]. It's easy to say what is essential, but how you define it, that's very difficult. These ESG research } \\
\text { institutes weigh more heavily those ESG factors than short-term impacts." (Manager, Firm 20) } \\
\text { 3G1. "Of course, I would like to think that since we're talking a lot about responsibility and environmental sustainability, and they're a } \\
\text { strong theme in our marketing communications, one could think that awareness raising among our stakeholders would also bear fruit for } \\
\text { preserving nature's wellbeing. Bringing the stories of raw materials and products to life in different channels. (Manager, Firm 12) } \\
\text { 3G2. "I myself have noticed that, for example, the word biodiversity, it's sometimes a challenging term to understand, what it means, } \\
\text { and nature's diversity is not necessarily a term that is easily understood either, but then those practical examples of why we do this, that } \\
\text { perhaps helps in its understanding. People can understand deforestation ... We're not necessarily talking about biodiversity as such } \\
\text { except with those stakeholders who are familiar with the term, but we're trying to bring it up with practical examples, showing what are } \\
\text { those practical steps. In my opinion, for example, one very good thing and something that also works in practice is adhering to the } \\
\text { [NGO] fish guide." (Director/Executive, Firm 11) }\end{array}$ \\
\hline
\end{tabular}


